\title{
The phenomenon of MSM behavior of students in Surabaya
}

\author{
Prakrisno Satrio Roesfandi \\ Faculty of Psychology \\ Airlangga University \\ Surabaya, Indonesia \\ prakrisno@gmail.com
}

\author{
Satryo Dewanto \\ Faculty of Psychology \\ 45 University Surabaya \\ Surabaya, Indonesia \\ satryod30@gmail.com
}

\begin{abstract}
Adolescence is a period of transition into adulthood, which they should begin to prepare for adulthood, including the sexual aspect. Many similar studies on premarital sexual behavior in adolescents conducted and published in Indonesia, but this study discusses specifically the behavior of MSM (Men Sex with Men) in adolescents. Using phenomenology approach on five adolescents from MSM community, this research discusses the fact of sexual behavior phenomenon that happened to adolescent boys today. Found that several factors affect them to do MSM behavior such as knowledge, emotional affection, facility, and persuasion. This study is a scientific proof of the behavioral phenomenon of MSM in teenage boys in Surabaya which may be not many people know and continue to be the subject of discussion.
\end{abstract}

Keywords-adolescent; MSM behavior; premarital sex behavior; identity

\section{INTRODUCTION}

The discussion of adolescent problems has become a social reality in society. Adolescence is a period of transition into adulthood, where they should begin preparing themselves for adult life, including in the sexual aspects. It is undeniable that the sexual aspect (other than the physical, psychological, and socio-emotional aspects) also includes one aspect to be considered in adolescent development [1]. The age of 15-20 years is called adolescence proper and is the culmination of emotional development. At this stage, there is a change of selfish tendency toward the tendency to notice the interests of others and the tendency to pay attention to self-esteem. Another symptom that arises at this stage is the rise of sex drive. Of the desires that exist in their bodies, sexual desire is the most urgent, and in this case, they show a loss of selfcontrol.

Various data from various institutions both public and private shows that the sexual aspect of adolescents is one of the problems of adolescents that must be discussed in social reality in Indonesia today. According to PKBI DIY in the Fact Sheet from PKBI Pusat, BKKBN and UNFPA in 2005 stated that as many as $15 \%$ of Indonesian teenagers ever had sexual intercourse [2]. According to Dinkes Surabaya [3] in the results of Indonesia Adolescent Reproductive Health Survey (SKI) in 2007 showed that $6.4 \%$ of boys and $1.3 \%$ of girls have premarital sex. So it can be concluded that sexual intercourse or premarital sex is true is a social reality that has occurred in many communities.

According to the results of a study from Rahyani, Utarini, Wilopo, and Hamiki [4], said that boys in high school (SMA) and in junior high school (SMP) more pre-marital sex (40,3\% and $29.4 \%$ ) compared with adolescent girls (3.6\% and $12.5 \%$ ). From all these emerging data it can be concluded that the intensity of premarital sex in adolescent boys in junior high and high school is higher than a female adolescent. However, the facts behind the high intensity of premarital sex that the teenage boys have not revealed.

According to data from GF, PKBI Jatim [5] shows that there are KD (Group Supported) LSL (Male Sex Men) aged 14-25 years are affordable in July-December 2016 in the city of Surabaya amounting to 553 people. KD or Group Assistance is a group of people of a certain age range who are accompanied to obtain information and access to free health related to their sexual and reproductive health. While LSL is an abbreviation of Male Sex with Men, taken from the word MSM (Men who have Sex with Men), a word given by health epidemiologists in the early 1990s that illustrates a new naming concept of male community performing sex with the same sex of men as well. Male Sex Men (MSM) are not necessarily gay or homosexual, conditions or circumstances that encourage them to engage in similar relationships such as in prisons, in settlements before the war, or where unemployed working men.

Similarly, adolescent boys in this study, their identity or sexual orientation were not yet fully established, but in fact, they continued to have sex with other men in various conditions such as the rise of sex drive or a living-like condition that contained all men which encourages them to do such behavior. 


\section{METHOD}

This research uses the qualitative method with phenomenology approach. Participants in this study were five teenagers aged 18-19 years who just sat in college in Surabaya. In addition to the data obtained from the participants, researchers also observed in their Line group "Surabaya City," several other groups where they were members of the group separately, and interviewed several people close to the participants (such as ex-boyfriends, close friends).

\section{RESULT}

This study found clear evidence that there are more than 60 teenage boys in Surabaya who have done MSM behavior and not all boys aged 18-19 years, there are 21-28 years old, and even some who have not 17 years old. They are all members of one of the LSL groups in the "Surabaya City" Line who live in Surabaya City with a total membership of 60 people. Not counting from other groups with more number of members because the group covers the whole area of Indonesia or even globally as well as other similar groups who are also domiciled in Surabaya alone or Surabaya-Sidoarjo-Gresik and so forth.

Not everyone in the Surabaya City group acknowledged directly that they were doing MSM behavior, but the data obtained from observations and short interviews with their significant others stated that everyone in the group had been doing MSM behaviors. This fact is gleaned from their former interconnected and with the help of the group admin who mentioned that he only invited children he had known before from his ex-girlfriend or former gebetan. In fact, almost every child in this group has ever performed an LSL behavior with an admin before entering the group.

From 5 participants, found some factors that shape and reinforce the behavior of MSM (they are most courageous to be directed): 1) performing MSM, 2) Continuing with previous people, 3) Lonely at home, 4) Having the same knowledge, 5) Never discussed previous sexuality with parents, 6) got a lot of attention, 7) invitation from, 8) Acted as recipient, 9) Looking for profit.

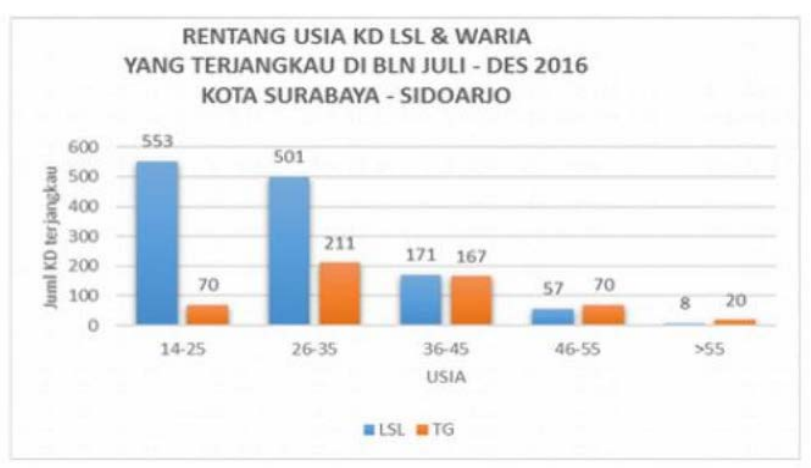

Fig. 1. Data of KD LSL and TG of GF PKBI East Java [5]

\section{DISCUSSION}

Regardless of their sexual orientation, the conditions or circumstances that encourage them to engage in this same-sex behavior are interesting to discuss. All subjects in this study have similarities that once had the behavior of MSM with other men he knew. The man may be older than the subject (such as the acknowledgment of all subjects) but may also be the same age as the subject (such as A's subjects who once performed the behavior of MSM with the subject mates B and C).

From the pattern, they are more daring to do the behavior with strangers or have not known them before. They are more courageous because these people have no relationship whatsoever with family, relatives, or acquaintances of the subject's friends. As the subject of C says: "If you know you will be afraid of being reported to church or my parents", or the subject said E: "Fear of playing with strangers, but if you know the risk is higher, later if he wants to continue intimidation me so want to pass my friends or family".

Another factor that greatly influences the behavior is the facility of facilities and infrastructure. With the infrastructure of a reasonably comfortable dorm room and living alone without parental supervision makes it easy to perform any activity without anyone being suspected especially because he is male [1, p. 182]. Various means that make it easy for them to get to know each other is very easy to find, one of them is the Surabaya City group. Supported by motor vehicles provided by parents for their children who are aged 17 years and above or ojek online more and more, very helpful to strengthen the occurrence of such behavior.

Some of the subjects usually do not perform the behavior because they do not have a place or are not fit to meet. As in the subject $C$ whose house is never quiet because it is adjacent to the church and always come home late at night because of new student admissions activities so that the time is not suitable to meet. So that subject $\mathrm{C}$ can never be if it must meet in its place, always must be supported with infrastructure from the partner of LSL that invites him not like subject A and subject $\mathrm{E}$ which live alone without parental supervision.

All subjects understood that having sex with women would make the woman pregnant. Although using contraceptives such as condoms, the risk of women becoming pregnant persists even though the percentage is slightly reduced. They get this less comprehensive information from school and their parents. However, unfortunately, this kind of talk about sexuality is rarely discussed in the place of education or the family. In an interview, subject $C$ said: "Papa and mama will never discuss sex, things like this are taboo according to religious teachings." The obstacle in subject $C$ is that talk about sex is considered taboo in the family members who are religious. As a result, information on sexuality (whether it is identity, orientation, gender, and gender expression) is not delivered comprehensively and makes children embarrassed to talk about issues about their sexuality. Until finally, they choose to perform safe MSM behaviors from the risks of pregnancy and also free of all visible restrictions, such as subject B say: "ML (Making Love) with a guy is nice, it will 
not get pregnant, no one knows, and no need marriage, etc. just making love. It is good. Ha ha ha".

Some of the subjects received intense attention (such as good morning messages, good night, have eaten or not, busy now what, miss you, and so on) before they finally want to meet and perform the behavior of MSM (subject C, D, E). However, in some circumstances (such as nighttime or when supported by adequate means and infrastructure and increased sexual arousal) subjects can easily be invited to perform MSM behaviors. More attention from others gives an emotional impact on the subject. "I know he cares for me because he loves me," said subject A. "I want to have sex with him yes because I love him," said subject D. Sex (or the behavior of MSM in this case) is a sign proof that the subject loves his partner.

Despite all this, all subjects in this study acted as recipients or who were analyzed in the behavior of MSM. The uniformity of subjects who were teenagers early in college was a surprising finding. Of the five subjects in this study, only one subject had ever acted as a giver or an anal, and that was only one time.

In this connection, there are also some parties who take advantage by installing tariffs every time he performs the behavior of MSM such as subject B and his friends. Regardless of its orientation, the subjects admitted that they preferred to om-om or adult males than to the same age or even underage as they were more established, had more money, and could nurture the subject B.

It can be concluded that the discussion of adolescent problems viewed from the sexual aspect in relation to the behavior of MSM is very complicated, so it does not surprise many teenagers who ultimately choose to conduct the behavior of MSM especially supported by various factors that enable and strengthen them to perform such behaviors such as facilities and infrastructure, knowledge the less comprehensive, the attention, and the solicitation.

\section{REFERENCES}

[1] Sarwono, Psikologi Remaja [Adolescent Pyschology]. Jakarta: Rajawali Pers, 2015.

[2] PKBI Pusat, BKKBN, and UNFPA Fact Sheet, 2005. [Online]. Available: https://pkbi-diy.info/perilaku-seksual-remaja/.

[3] Surabaya Health Board, Survei Kesehatan Reproduksi Remaja Indonesia (SKRRI) [Indonesian Adolescent Reproduction Health Survey], 2007. Available at: http://dinkes.surabaya.go.id/portal/puskesmasku/peduliremaja-giatkan-posyandu-remaja/.

[4] Rahyani, Utarini, Wilopo, and Hamiki, Jurn. Keseh. Masy. Nas., vol. 7, no. 4, November 2012.

[5] East Java’s GF PKBI, Laporan Narasi SSR GF PKBI Jatim Bulan JuliDesember Kota Surabaya-Sidoarjo [Narration Report of SSR GF PKBI East Java, July to Desember for Surabaya and Sidoarjo]. Surabaya: GF PKBI Jatim, 2016. 